\title{
Person-Organization Fit and Organizational Sustainability: A Case of Selected Banks in Ekpoma, Edo State
}

\author{
Dr. Osagie, N.G ${ }^{1}$, Ohue Paul Itua ${ }^{2 *}$ \\ ${ }^{I}$ Department of Business Administration, Faculty of Management Sciences, Ambrose Alli University, Ekpoma, \\ Edo State; Nigeria \\ ${ }^{2}$ Department of Business Administration, Faculty of Management Sciences, Nnamdi, Azikiwe University, Awka, \\ Anambra State; Nigeria
}

*Corresponding Author: Ohue Paul Itua, Department of Business Administration, Faculty of Management Sciences, Nnamdi, Azikiwe University, Awka, Anambra State; Nigeria

\begin{abstract}
The broad objective of this paper is to determine the effect of person-organization fit on the organizational sustainability of selected banks in Ekpoma, Edo State. Specifically, this paper seeks to ascertain the effect of employee personal value on the competency of selected banks in Ekpoma, Edo State. Survey research design was adopted for the study, a total population of one hundred and twenty three (123) was used for the study, complete enumeration sampling method was used for the study because the population is a manageable size, the data collection tool employed by the researcher was the questionnaire, while the analysis of the data was done using the linear regression analysis. The findings revealed that employee personal value impacts the competency of selected banks in Ekpoma, Edo State since $(F=233.041 ; R 2=$ 0.852; $P<.05)$. The researcher therefore concluded that person-organization fit impacts the sustainability of the banks in focus. It was against this backdrop that the researchers recommended an identification of the personal values of prospective employees by the human resources department during the recruitment and selection process and only individuals whose personal values aligns with that of the organization should be employed.
\end{abstract}

Keywords: Person-Organization Fit, Organizational Sustainability, Employee Personal Value, Competency

\section{INTRODUCTION}

Today, organizations operate in a very competitive global environment. Given the fact that the major expense for most organizations is the cost of labour, steps that can be taken to reduce these costs will be beneficial. While downsizing can be effective, these approaches have their own costs. Studies have shown that Person-organization fit approach could impact the sustainability of an organization (Silversthorne, 2004). The banking industry has been recognised as a pillar of economic growth and development in developed and developing countries (Levine, 1997).

The recognized contribution of the banking industry towards the economic growth of a nation has led to the study of the human element in selected commercial banks in Ekpoma, Edo State. This gives credence to the determination of the effect of person-organization fit on the sustainability of selected commercial banks in Ekpoma, Edo State. Person-Organization fit (P-O fit) is defined as the "compatibility between people and organizations that occurs when at least one entity provides what the other needs or they share similar fundamental characteristics or both"(Kristof-Brown, Zimmerma \& Johnson (2005).

The employees of business organizations are responsible for the implementation of the various strategies and processes enacted by management. Therefore, the employment of employees who has good fit with the organization is imperative (Kalleberg, 2000 cited in Sekiguchi, 2007). When there is a good fit between employees and their organizations, it could impact the sustainability of the organization (Castka, Bamber, Sharp \& Belohoubek, 2001). An organization's sustainability can be determined by its ability to achieve its set goals and objectives. Robbins and Judge (2009) opine that business organizations exists in a dynamic and changing environment and requires employees who are able to readily able to impact the sustainability of the organization. 
The commercial banks in Ekpoma used for the study are Guaranty Trust Bank (GTB), First Bank Nigeria Plc, Union Bank Nigeria Plc, Fidelity Union Bank Nigeria Plc and Zenith Bank Nigeria Plc.

The researchers observed that the personal values of some employees of the banks in focus do not align with that of their organization. This by extension could impact the competency level of these organizations.

The broad objective of this study is to determine the effect of person-organization fit on the sustainability of selected banks in Ekpoma, Edo State.

Specifically, this study seeks to ascertain the effect of employee personal value on the competency of the banks in focus.

\section{REVIEW OF RELATED LITERATURE}

\subsection{Conceptual Review}

\subsubsection{Person-Organization Fit ( $P$-O fit)}

Person-Organization fit (P-O fit) is defined as the "compatibility between people and organizations that occurs when at least one entity provides what the other needs or they share similar fundamental characteristics or both" (Kristof-Brown, Zimmerma \& Johnson (2005). Person-organization fit can also be defined as the congruence between an individuals' interests and abilities and the characteristics and requirements of their job (Carless 2005; Christensen, Wright 2011), and is considered to be among the major determinants of work outcomes and the components of working life, which has the power to directly affect organizational performance (Nikolaou 2003). P-O fit is a situation whereby people may fit or misfit (Judge\& Kristof-Brown, 2004). P-O fit takes place when the organization fulfils employee's needs and from the abilities-demands perspective, there is congruence between the person and the organization (Kristof, 1996).

Van Vianen, De Pater and Van Dijk (2007) elaborates that people's fit with the organization (P-O fit) associates a person's personality, goals and values with those of the organization.

This study is centred on the alignment of employee personal values with that of the organization.

\subsubsection{Employee Personal Value}

Employee personal value is enduring beliefs that influence an employee's attitude in the work environment. Employee personal value influences employee actions, attitudes, judgement and comparisons across situations in an organization (Long \& Shiffman, 2000). Clark and Micken (2002) are of the opinion that personal value impacts the decisions of employees in an organization.

The list of value (LOV) developed by Kahle, (1983) was used for this study. The LOV consists of nine Personal value values; sense of belonging, sense of accomplishment, fun and enjoyment, warm relationship, excitement, being well respected, security, self respect and self fulfillment.

\subsubsection{Organizational Sustainability}

Colbert and Kurucz (2007) see organizational sustainability as being able to "keep the business going", whilst another frequently used term in this context refers to the "future proofing" of organizations. Boudreau and Ramstad (2005), refer to organizational sustainability as "achieving success today without compromising the needs of the future". According to the Chartered Institute of Personnel and Development (CIPD, 2012), the essence of sustainability in an organizational context is "the principle of enhancing the societal, environmental and economic systems within which a business operates". This is reflected also by Colbert and Kurucz (2007), who state that organizational sustainability "implies a simultaneous focus on economic, social, and environmental performance".

Eccles, Ioannou and Serafeim, (2011) note that organizations are developing sustainability policies, but they highlight that these policies are aimed at developing an underlying "culture of sustainability", through policies highlighting the importance of the environmental and social as well as financial performance. These policies seek to develop a culture of sustainability by articulating the values and beliefs that underpin the organization's objectives.

\subsubsection{Organizational Competence}

Organizational competence is defined as the ability to do something (Mills, Boume, \& Richards, 2002). An organization is said to be highly competent when it is capable of beating its competitors in 
a given factor. As such, it is not something that an organization has or stops having, but rather something it has in a certain level. The debate over competences is not recent and a great diversity of competence concepts exist (Bitencourt 2005). Organizational competence is a continuous and articulate process of formation and development of know-how, skills and attitudes in which the individual is responsible for the construction and consolidation of his/hers competences (selfdevelopment) by interacting with other people in the workplace, family, and/or other social groups (extended scope), with the aim of improving his/hers capacity, in order to add value to the organization's activities and to oneself (self-realization) (Bitencourt, 2005)." Organizational competence must aggregate economic value to the organization and social value to the individual (Teece, Pisano, \& Shuen 1991).

Organizational competences can be explained as consisting of a combination of corporate characteristics, abilities, motivations and know-how. These mechanisms are incorporated in their systems and processes and are spread between their collaborators and structures (Turner \& Crawford, 1994).

\subsection{Theoretical Framework}

This study is anchored on Resource Based Theory propounded by Robert Grant in (1996). The resource-based theory comprises a rising and dominant area of the strategy literature which addresses the question of an organization's identity and it is principally concerned with the source, nature and utilization of strategic capabilities. The basis of the resource-based theory is that successful firms will find their future competitiveness on the development and utilization of distinctive and unique capabilities, which may often be implicit or intangible in nature (Teeche, Pinsno \& Shuen, 1991).

\subsection{Empirical Review}

Demir, Demir and Nield (2015) examined the relationship of person-organization fit in hotels through organizational identification, job performance, production deviance behavior and intention to remain. Five hundred and eighty two (582) respondents were used for the study, questionnaire was the data collection tool used to collect data from employees of five-star hotels operating within the Mugla region of Turkey. Structural equation modeling was used to analyse the data. Findings of the study showed that person-organization fit have significant and positive influence on organizational identification, job performance and intention to remain.

Nabil, (2016) examined the relationship between person-organization fit, burnout and turn-over intention among Canadian international college academic staff. A population of two hundred and fifty (250) respondents was used for the study, questionnaire was the data collection tool employed, chisquare statistical tool and Pearson product moment correlation coefficient was used to analyse the collected data. Findings of the study revealed a relationship between person-organization fit and burnout and a negative relationship between person-organization fit and turn-over intention

Icheme, (2017) examined the implication of personnel selection, person-organization fit and job-fit on employee performance in Nigerian business organizations. The study revealed that the recruitment and selection process determines person-organization fit and job-fit in business organizations.

Arambewela and Hall (2011) examined the role of personal value in enhancing student experience and satisfaction among international post-graduate students. The study focused on four groups of Asian students studying in Australian universities. Multivariate data analysis and structural equation modeling was used for the study. The study revealed that person-organization fit are predictors of student experience and satisfaction.

\subsection{Gap in Knowledge}

None of the empirically reviewed examined person-organization fit as it relates to the sustainability of selected banks in Ekpoma, Edo state. This is the gap in knowledge that this study intends to fill.

\section{Methodology}

\subsection{Research Design}

The research design adopted for this study was the survey research design. It was used because of the nature of the study. Survey research design enables the researcher to observe what happens to the sample subjects without manipulating them. 
Person-Organization Fit and Organizational Sustainability: A Case of Selected Banks in Ekpoma, Edo State

\subsection{Population of Study}

Table1. List of Commercial Banks in Ekpoma, Edo State

\begin{tabular}{|l|l|}
\hline \multicolumn{1}{|c|}{ Institution } & \multicolumn{1}{c|}{ Location } \\
\hline Union Bank Nigeria Plc, Ekpoma. & Royal Market Road, Ekpoma \\
\hline First Bank Nigeria Plc, Ekpoma. & Royal Market Road, Ekpoma \\
\hline Guaranty Trust Bank Nigeria Plc, Ekpoma. & Ihumudumu Road, Ekpoma \\
\hline Key Stone Bank, Ekpoma & Alli Square, Ekpoma. \\
\hline Access Bank, Ekpoma & Akere Lane, Ekpoma. \\
\hline United Bank for Africa (UBA) Plc, Ekpoma. & Ukpenu Road, Ekpoma. \\
\hline Zenith Bank Nigeria Plc, Ekpoma & Ukpenu Road, Ekpoma. \\
\hline ECO Bank, Ekpoma & Royal Market Road, Ekpoma. \\
\hline Fidelity Bank Nigeria Plc, Ekpoma. & Ihumudumu Road, Ekpoma \\
\hline
\end{tabular}

Table2. Population of Employees in the Banks of Study

\begin{tabular}{|c|c|}
\hline Institution & Total Population \\
\hline Union Bank Nigeria Plc, Ekpoma. & 24 \\
\hline First Bank Nigeria Plc, Ekpoma. & 29 \\
\hline Guaranty Trust Bank Nigeria Plc, Ekpoma. & 22 \\
\hline Fidelity Bank Nigeria Plc, Ekpoma & 21 \\
\hline Zenith Bank Nigeria Plc, Ekpoma & 27 \\
\hline Total & 123 \\
\hline
\end{tabular}

Source: Personnel Department of the Institutions of Study

\subsubsection{Sample Size and Sampling Technique}

Complete enumeration sampling method was used for the study because the study population of one hundred and twenty three (123) is a manageable size.

\subsubsection{Instrument of Data Collection}

The data collection tool employed by the researcher was the questionnaire. It was designed on a five point Likert Scale. Strongly Agreed (SD), Agreed (A), Undecided (U), Strongly Disagreed (SD) and Disagreed (D).

\subsubsection{Validity of the Instrument}

Validity is the extent to which an instrument measures what it intends to measure. The content and face validity test was used by the researcher.

\subsubsection{Reliability of the Instrument}

This is a measure of the consistency of a particular instrument employed by a researcher. The Cronbach's Alpha reliability test was used for the study. Suwannoppharat and Kaewsa, (2015) asserts that a reliability coefficient of 0.696 and above is acceptable. Therefore, a benchmark of 0.696 was used for the study.

Table3. Scale: Reliability Statistics for Person-Organization fit

\begin{tabular}{|l|l|l|}
\hline \multicolumn{2}{|c|}{ Reliability Statistics } \\
\hline Cronbach's Alpha & \multicolumn{1}{c|}{ N of Items } \\
\hline .757 & 5 \\
\hline
\end{tabular}

Source: Field survey, 2018

Since the Cronbach's Alpha score of the reliability statistics for person-organization fit $0.76>0.696$, it shows that the instrument is reliable.

Table4. Scale: Reliability Statistics for Organizational Sustainability

\begin{tabular}{|l|l|l|}
\hline \multicolumn{2}{|c|}{ Reliability Statistics } \\
\hline \multicolumn{2}{|c|}{ Cronbach's Alpha } & 5 \\
\hline .770 & N of Items \\
\hline
\end{tabular}

Source: Field survey, 2018 
Since the Cronbach's Alpha score of the reliability statistics for organizational Sustainability $0.77>0.696$, it shows that the instrument is reliable.

The results of the reliability test were indications of the internal consistency of the instrument.

\subsection{Method of Data Analysis}

Linear regression analysis was used to analyse the collected data. This was done with the aid of Statistical Package for Social Sciences (SPSS) version 20.

\section{Data Presentation And Analysis}

Table5. Table of Returned and Unreturned Questionnaire

\begin{tabular}{|l|c|c|}
\hline \multicolumn{2}{|c|}{ Analysis of Returned and Unreturned Questionnaire } \\
\hline & Frequency & Percentage (\%) \\
\hline Returned Questionnaire (Valid) & 87 & 70.73 \\
\hline Returned Questionnaire (Invalid) & 08 & 06.51 \\
\hline Unreturned Questionnaire & 28 & 22.76 \\
\hline Total Questionnaire Administered & 123 & 100 \\
\hline
\end{tabular}

Source: Field Survey, (2018)

The table above shows that out of the 123 copies of the questionnaire administered, 87 valid questionnaires were retrieved. Based on that, 87 copies of the questionnaire were used for the analysis.

Table6. Descriptive Statistics of the Analysed Data (Person-Organization fit)

\begin{tabular}{|l|l|l|l|}
\hline \multicolumn{2}{|c|}{ Item Statistics } \\
\hline & \multicolumn{1}{|c|}{ Mean } & Std. Deviation & N \\
\hline Q1 & 3.1667 & 1.42408 & 87 \\
\hline Q2 & 3.2619 & 1.27234 & 87 \\
\hline Q3 & 3.3968 & 1.36282 & 87 \\
\hline Q4 & 3.5206 & 1.34077 & 87 \\
\hline Q5 & 3.4841 & 1.40134 & 87 \\
\hline
\end{tabular}

Since the mean score of all the items (Q1-5) is greater than 3.00 which was the benchmark used, it shows that all the questions are acceptable and can be used for the analysis.

Table7. Descriptive Statistics of the Analysed

Data (Organizational Sustainability)

\begin{tabular}{|l|l|l|l|l|}
\hline \multicolumn{2}{|c|}{ Mean } & Item Statistics & N \\
\hline & \multicolumn{2}{|c|}{ Std. Deviation } & 87 & \\
\hline Q1 & 3.1508 & 1.43146 & 87 \\
\hline Q2 & 3.1429 & 1.28196 & 87 \\
\hline Q3 & 3.2619 & 1.38667 & 87 \\
\hline Q4 & 3.5175 & 1.33057 & 87 \\
\hline Q5 & 3.4603 & 1.38939 & \\
\hline
\end{tabular}

Since the mean score of all the items (Q1-5) is greater than 3.00 which was the benchmark used, it shows that all the questions are acceptable and can be used for the analysis.

\subsection{Test of Hypothesis}

Ho: Employee value does not affect the organizational competence of selected banks in Ekpoma, Edo State.

Table8. Model Summary of Regression Output

\begin{tabular}{|c|c|c|c|c|c|c|c|c|c|}
\hline \multicolumn{10}{|c|}{ a) Model Summary } \\
\hline \multirow[t]{2}{*}{$\mathbf{R}$} & \multirow{2}{*}{$\begin{array}{c}\mathbf{R} \\
\text { Square }\end{array}$} & \multirow{2}{*}{$\begin{array}{c}\text { Adjusted } \\
\text { R } \\
\text { Square } \\
\end{array}$} & \multirow{2}{*}{$\begin{array}{l}\text { Std. Error } \\
\text { of the } \\
\text { Estimate }\end{array}$} & \multicolumn{5}{|c|}{ Change Statistics } & \multirow{2}{*}{$\begin{array}{l}\text { Durbin- } \\
\text { Watson }\end{array}$} \\
\hline & & & & $\begin{array}{r}\mathrm{RS} \\
\mathrm{Cl}\end{array}$ & $\begin{array}{c}\mathbf{F} \\
\text { Change }\end{array}$ & df1 & df2 & $\begin{array}{c}\text { Sig. F } \\
\text { Change }\end{array}$ & \\
\hline $914^{\mathrm{a}}$ & .852 & .825 & .62122 & .818 & 233.041 & 1 & 52 & .000 & 1.879 \\
\hline
\end{tabular}

a. Predictors: (Constant), Employee Value

b. Dependent Variable: Organizational Competence

International Journal of Managerial Studies and Research (IJMSR) 
Person-Organization Fit and Organizational Sustainability: A Case of Selected Banks in Ekpoma, Edo State

Table9. ANOVA Result from Regression Output

\begin{tabular}{|c|c|c|c|c|c|c|}
\hline \multicolumn{7}{|c|}{ a) ANOVAa } \\
\hline & Model & Sum of Squares & Df & Mean Square & $\mathbf{F}$ & Sig. \\
\hline \multirow{3}{*}{1} & Regression & 89.933 & 1 & 89.933 & 233.041 & $.000^{\mathrm{b}}$ \\
\hline & Residual & 20.067 & 52 & .386 & & \\
\hline & Total & 110.000 & 53 & & & \\
\hline
\end{tabular}

Table10. Coefficients from Regression Output

\begin{tabular}{|c|c|c|c|c|c|c|c|c|}
\hline \multicolumn{9}{|c|}{ b) Coefficients $^{\mathbf{a}}$} \\
\hline & \multirow[t]{2}{*}{ Model } & \multicolumn{2}{|c|}{$\begin{array}{l}\text { Unstandardized } \\
\text { Coefficients }\end{array}$} & \multirow{2}{*}{$\begin{array}{c}\begin{array}{c}\text { Standardized } \\
\text { Coefficients }\end{array} \\
\text { Beta }\end{array}$} & \multirow[t]{2}{*}{$\mathbf{T}$} & \multirow[t]{2}{*}{ Sig. } & \multicolumn{2}{|c|}{$\begin{array}{l}\text { 95.0\% Confidence } \\
\text { Interval for B }\end{array}$} \\
\hline & & $\mathbf{B}$ & $\begin{array}{l}\text { Std. } \\
\text { Error }\end{array}$ & & & & $\begin{array}{l}\text { Lower } \\
\text { Bound }\end{array}$ & $\begin{array}{l}\text { Upper } \\
\text { Bound }\end{array}$ \\
\hline \multirow[t]{2}{*}{1} & (Constant) & .292 & .197 & & 1.484 & .144 & -.103 & .686 \\
\hline & $\begin{array}{l}\text { Employee } \\
\text { Value }\end{array}$ & .908 & .060 & .904 & $\begin{array}{r}15.26 \\
6 \\
\end{array}$ & .000 & .789 & 1.028 \\
\hline
\end{tabular}

The result obtained from the regression analysis shows that employee value significantly and positively impacts organizational competence $(\beta=0.904, \mathrm{t}=15.266, \mathrm{P}<.05)$. Also, employee value is a predictor of organizational competence $(\mathrm{F}=233.041 ; \mathrm{R} 2=0.852 ; \mathrm{P}<.05)$. The predictor variable single handedly explained $85.2 \%$ of the variance in organizational competence, while the remaining $14.8 \%$ could be due to the effect of extraneous variables. The durbin-watson value of 1.9 shows that there is no first order serial correlation.

\section{Discussion OF FINDINGS, SUMMARY, CONCLUSION AND RECOMMENDATIONS}

\subsection{Discussion of Findings}

The result obtained from the regression analysis shows that employee value significantly and positively impacts organizational competence. This corroborates the work of Demir, Demir and Nield (2015). They examined the relationship of person-organization fit in hotels through organizational identification, job performance, production deviance behavior and intention to remain. Findings of the study showed that person-organization fit (personal value) have significant and positive influence on organizational identification, job performance and intention to remain. The work of Nabil, (2016) is also in line with the result obtained from the test of the formulated hypothesis. The study examined the relationship between person-organization fit, burnout and turn-over intention among Canadian international college academic staff. Findings of the study revealed a relationship between personorganization fit (personal value) and burnout. The work of Arambewela and Hall (2011) also corroborates the findings obtained from the test of the formulated hypothesis. The study examined the role of personal value in enhancing satisfaction. The study revealed that person-organization fit is a predictor of satisfaction. In other words, personal value impacts organizational competency.

\subsection{Summary of Findings}

Findings from the test of the formulated hypothesis shows that employee value impacts organizational competence of selected banks in Ekpoma, Edo State since $(\mathrm{F}=233.041 ; \mathrm{R} 2=0.852 ; \mathrm{P}<.05)$.

\subsection{Conclusion}

Based on the findings, the researchers concluded that person-organization fit impacts the sustainability of selected banks in Ekpoma, Edo State. The findings of the study shows that when the personal values of employees aligns with that of the organization, it could impact the competency level of the banks in focus.

\subsection{Recommendations}

The researchers made the following recommendations based on the findings of the study:

- Identification of the personal values of prospective employees by the human resources department during the recruitment and selection process. 
- The human resources department of the banks in focus should make sure that only individuals whose personal values aligns with that of the organization are employed.

\section{REFERENCES}

[1] Arambewela, R. \& Hall, J. (2011). The Role of Personal Value in Enhancing Student Experience and Satisfaction among International Postgraduate Students: An Exploratory Study.

[2] Bitencourt, C.C. (2005). Organizational Learning and a Firm's Core Competence. In: Competence-based Competition, Hamel G, Heene A (eds.). London: John Wiley \& Sons.

[3] Boudreau, J. \& Ramstad, P. (2005). Talentship, Talent Segmentation, and Sustainability: A new HR Decision Science Paradigm for a New Strategy Definition. Human Resource Management, 44(2), 129-136.

[4] Carless, S.A. (2005). Person-Job Fit Versus Person-Organization Fit as Predictors of Organizational attraction and Job Acceptance Intentions: A Longitudinal Study. Journal of Occupational and Organizational Psychology, 78: 411-429.

[5] Castka, P., Bamber, C.J., Sharp, J.M. \& Belohoubek,P. (2001). "Factors Affecting Successful Implementation of High Performance Teams". Team Performance Management International Journal of Business and Management, 7,(7/8)123-134.

[6] CIPD (2012). Responsible and Sustainable Business: HR leading the way - A Collection of "Thought Pieces". London: CIPD.

[7] Clarke, I. \& Micken, S. (2002). An Exploratory Cross Cultural Analysis of Values of Materialism. Journal of International Consumer Marketing, 14(4), 85-89.

[8] Colbert, B. \& Kurucz, E. (2007). Three Conceptions of Triple Bottom Line Business Sustainability and the role for HRM, Human Resource Planning 30(1).

[9] Demir, M., Demir, S.S. \& Nield, K. (2015). The Relationship between Person-Organization fit, Organizational Identification and Work Outcomes. Journal of Business Economics and Management, 16 (2): 369-386.

[10] Eccles, R., Ioannou, I. \& Serafeim, G. (2011). The Impact of a Corporate Culture of Sustainability on Corporate Behaviour and Performance. Harvard Business School Working Paper 12-035.

[11] Grant, R. M. (1996). Toward a Knowledge-based Theory of the Firm. Strategic Management Journal, 17, 109-122.

[12] Icheme, M. (2017). Personnel Selection, Person-Organization fit and Job-fit: Implications for Employee Performance in Nigeria. IJSRM, 5.

[13] Judge, T.A \& Kristof-Brown,A. (2004). "Personality, Interactional Psychology, and Person Organization Fit", in Personality and Organizations, eds. B.Schneider and D.B. Smith. New Jersey: Lawrence Erlbaum Associates.

[14] Kahle, L.R. (1983). Social Values and Social Change: Adaptation to Life in America. New York: Praeger.

[15] Kristof-Brown, A.L. (1996). "Person-Organization Fit: An Integrative review of its Conceptualizations, Measurement and Implications", Journal of Personnel Psychology, 49,1-49.

[16] Kristof-Brown, A.L., Zimmerman, R.D. \& Johnson,E.C. (2005), "Consequences of Individuals" Fit at Work: a Meta-analysis of Person-job, Person-organization, Person-group, and Person supervisor Fit", Journal of Personnel Psychology,58, 281-342.

[17] Levin, R. (1997). Financial Development and Economic Growth: Views and Agenda. Journal of Economic Literature, 35.

[18] Long, M.M. \& Schiffman, L.G. (2000). Consumption Values and Relationships: Segmenting the Market for Frequency Programs. Journal of Consumer Marketing, 17(3), 214-232.

[19] Mills J, Boume M, \& Richards, H. (2002). Competing through Competences. Cambridge: University Press.

[20] Nabil, E. (2016). The Relationship between Person-Organization fit, Burnout and Turn-over Intention among Canadian International College Staff. The Business and Management Review, 7(2): 53-66.

[21] Nikolaou, I. (2003). Fitting the Person to the Organization: Examining the Personality-Job-Performance Relationship from a new Perspective. Journal of Managerial Psychology, 18 (7): 639-648.

[22] Robbins, S.P. \& Judge, T.A. (2009). Organizational Behavior $13^{\text {th }}$ Ed. Upper Saddle River, New Jersey: Pearson Prentice Hall.

[23] Sekiguchi, T. (2007), "A Contingency Perspective of the importance of PJ fit and PO fit in Employee Selection", Journal of Managerial Psychology, 22, 2,118-131.

[24] Silverthorne, C. (2004). "The impact of Organizational Culture and Person Organization fit on Organizational Commitment and job satisfaction in Taiwan".The Leadership \& Organization Development Journal, 25, 7, 592-599. 
[25] Suwannoppharat, K. \& Kaewsa, A. (2015). Utilization of Content. Theme Based Instruction: An Overhaul of English Language Learning for Non-native English Learners. International Journal of English Language Education, 1(3), 115-126.

[26] Teece D.J, Pisano G. \& Shuen A. (1991). Dynamic Capabilities and Strategic Management. Strategic Management Journal, 18(7): 509-533.

[27] Turner, D. \& Crawford M. (1994). Managing Current and Future Competitive Performance: The Role of Competence. In: Competence-based Competition, Hamel G. \& Heene, A. (eds.). London: John Wiley \& Sons.

[28] Van-Vianen, A.E.M., De Pater, I.E. \& Van-Dijk,F. (2007). "Work Value Fit and Turn-over Intention: Same-source or Different-source Fit”, Journal of Managerial Psychology, 22, 2,188-202.

\section{APPENDIX 1}

\section{Questionnaire Items on Person-Organization Fit and Organizational Sustainability}

Options: Strongly Agree = SA, Agree = A, Undecided = UD, Strongly Disagree = SD, Disagree = D. Please tick ( $\square$ ) as it represents your view

\begin{tabular}{|c|c|c|c|c|c|c|}
\hline & $\begin{array}{l}\text { Questionnaire Item for Independent Variable(Person- } \\
\text { organization fit) }\end{array}$ & & & & & \\
\hline No & Personal Value & $\begin{array}{l}\text { SA } \\
5\end{array}$ & $\begin{array}{l}\mathbf{A} \\
4\end{array}$ & $\begin{array}{l}\text { UD } \\
3\end{array}$ & $\begin{array}{l}\text { SD } \\
2\end{array}$ & $\begin{array}{l}\mathbf{D} \\
\mathbf{1}\end{array}$ \\
\hline 1 & You believe in the goals and objectives of your organization. & & & & & \\
\hline 2 & You have a cordial relationship with your colleagues. & & & & & \\
\hline 3 & You will like to rise to the apex in your organization. & & & & & \\
\hline 4 & $\begin{array}{l}\text { You are always happy when there is an increase in the profit } \\
\text { margin of your organization. }\end{array}$ & & & & & \\
\hline \multirow[t]{3}{*}{5} & You have a good relationship with customers. & & & & & \\
\hline & Dependent Variable (Organizational Sustainability) & & & & & \\
\hline & Organizational Competence & & & & & \\
\hline 1 & $\begin{array}{l}\text { Your organization find it difficult to implement new policies of } \\
\text { Central Bank of Nigeria. }\end{array}$ & & & & & \\
\hline 2 & $\begin{array}{l}\text { You are able to cope with the ever increasing demands of } \\
\text { customers. }\end{array}$ & & & & & \\
\hline 3 & $\begin{array}{l}\text { Over time, the customer base of your organization has } \\
\text { increased. }\end{array}$ & & & & & \\
\hline 4 & $\begin{array}{l}\text { The report of the marketing department in your organization is } \\
\text { used during decision making. }\end{array}$ & & & & & \\
\hline 5 & $\begin{array}{l}\text { The target of your organization is to be number one in the } \\
\text { industry it belongs. }\end{array}$ & & & & & \\
\hline
\end{tabular}

\section{AUTHORS' BIOGRAPHY}

Osagie, N.G. PhD obtained his Bsc and Msc in Business administration from University of Ilorin, Kwara State, Nigeria. He obtained his PhD in management in 2012 from Ebonyi State University, Ebonyi State, Nigeria. He is presently an Associate Professor at Ambrose Alli University, Ekpoma Edo State, Nigeria.

Ohue Paul Itua obtained his Bsc in Business administration at Ambrose Alli University, Ekpoma Edo State, Nigeria in 2012. He obtained his Msc in Business administration at Nnamdi Azikiwe University Awka, Anambra State, Nigeria in 2017. He is presently a PhD student at Nnamdi Azikiwe University Awka, Anambra State, Nigeria.

Citation: Dr. Osagie, N.G, Ohue Paul Itua. "Person-Organization Fit and Organizational Sustainability: A Case of Selected Banks in Ekpoma, Edo State" International Journal of Managerial Studies and Research (IJMSR), vol 7, no. 4, 2019, pp. 78-85. doi: http://dx.doi.org/10.20431/2349-0349.0704011.

Copyright: (C) 2019 Authors. This is an open-access article distributed under the terms of the Creative Commons Attribution License, which permits unrestricted use, distribution, and reproduction in any medium, provided the original author and source are credited. 